\title{
PENGEMBANGAN BUKU CERITA BERGAMBAR BERKEARIFAN LOKAL SUBAK PADA TEMA PEDULI TERHADAP MAKHLUK HIDUP UNTUK SISWA KELAS 4 SEKOLAH DASAR
}

\author{
I.P.H. Wirawan', I.M. Gunamantha ${ }^{2}$, I.B. Putrayasa ${ }^{3}$ \\ ${ }^{123}$ Program Studi Pendidikan Dasar \\ Universitas Pendidikan Ganesha \\ Singaraja, Indonesia \\ e-mail: hendrawirawan@gmail.com ${ }^{1}$, md gunamantha@yahoo.com ${ }^{2}$, \\ ib.putrayasa@undiksha.ac.id ${ }^{3}$
}

\begin{abstract}
Abstrak
Masalah dalam penelitian ini adalah: 1) isi buku tematik tidak sesuai dengan lingkungan dan budaya tempat siswa belajar; 2) beberapa buku tidak menampilkan situasi konkrit/nyata ke dalam pembelajaran; 3) teknik penyajian buku tematik di Sekolah Dasar tidak mendukung prosedur pendekatan saintifik; dan 4) bahan ajar di Sekolah Dasar belum mampu mengembangkan kemampuan naratif siswa. Penelitian ini bertujuan untuk mengetahui: 1) validitas buku cerita bergambar berkearifan lokal subak dalam tema peduli terhadap makhluk hidup untuk siswa kelas 4 SD; 2) kepraktisan buku cerita bergambar berkearifan lokal subak dalam tema peduli terhadap makhluk hidup untuk siswa kelas 4 SD; 3) respon siswa terhadap buku cerita bergambar berkearifan lokal Subak dalam tema peduli terhadap makhluk hidup untuk siswa kelas 4 SD. Penelitian ini merupakan penelitian pengembangan yang mengadopsi model 4D (Define, Design, Develope, dan Disseminate). Data yang dikumpulkan berupa data validitas dan kepraktisan buku cerita. Data validitas diukur dengan uji validitas melibatkan 2 ahli. Data yang telah terkumpul kemudian dikonversi menggunakan skala likert. Data kepraktisan diukur berdasarkan respon guru dan siswa yang diperoleh dari responden yaitu 3 orang guru dan 23 siswa kelas IV. Hasil penelitian menunjukkan bahwa: 1) berdasarkan hasil uji validitas ahli, diperoleh rata-rata sebesar 4.91 yang berada pada kategori sangat valid. 2) berdasarkan hasil analisis respon guru diperoleh rata-rata sebesar 4.28 yang berada pada kategori sangat praktis. 3) berdasarkan hasil analisis respon siswa diperoleh persentase $94 \%$ dengan kategori sangat praktis. Berdasarkan hasil tersebut disimpulkan bahwa penelitian ini menghasilkan buku cerita anak bergambar yang valid dan praktis.
\end{abstract}

Kata kunci: Buku Cerita Anak; Kearifan Lokal; Kepraktisan; Subak; Validitas

\begin{abstract}
The current issue which is discussed are: 1) the content of thematic book is not accordance with the current environment and culture of the students; 2) some of the books are not showing a proper real situation on the learning process; 3) the delivery of thematic book doesn't align woth the scientific approach; and 4) The learning material at the elementary school is not able to develop the narrative skill of the student. This study aims to determine: 1) the validity of Development of Children's Story Book along the Local Wisdom of Subak with the Theme of Caring to the Living Creatures for Elementary School, $4^{\text {th }}$ Grade; 2) the practicality of subak local wisdom children's storybooks in the theme of care to organism for grade $4^{\text {th }}$ elementary school students; 3) students response of subak local wisdom children's storybooks in the theme of care to organism for grade $4^{\text {th }}$ elementary school students. This research adopted the $4 D$ model (Define, Design, Develop, and Disseminate). Collecting the validity data and practicality data was using manual data form. Two experts were involved in measuring the data validity. The collected data was using a Likert scale to present. Practicality data was estimated based on teacher and student responses as the object in this study: three teacher and 23 students of $4^{\text {th }}$ Grade. The results showed that: 1) it obtained an average of 4.91, which was in the excellent category. 2) based on the results of the teacher
\end{abstract}


response analysis, it obtained an average of 4.28, which is in the efficient category. 3) based on the results of the student response analysis, the percentage was $94 \%$ with the efficient category. These results concluded that these children's story book is valid and practical.

Keywords : Children's Story Books; Local Wisdom; Practicality; Subak; Validity

\section{PENDAHULUAN}

Pembelajaran di Sekolah Dasar merujuk pada pembelajaran tematik dengan pengintegrasian berbagai kompetensi dasar muatan pelajaran ke dalam berbagai tema. Majid (2017) mengungkapkan pengintegrasian yang dimaksud diantaranya pengintegrasian sikap, keterampilan, dan pengetahuan dalam proses pembelajaran dan integrasi berbagai konsep dasar yang terkait satu dengan yang lainnya. Tujuan dari pembelajaran ini yaitu memudahkan siswa dalam memahami materi pelajaran dan mengembangkan berbagai kemampuan siswa dalam tema tertentu. Tema-tema yang ditetapkan pada tiap jenjang kelas tentunya sudah disesuaikan dengan perkembangan kognitif peserta didik, serta disusun secara bertahap mulai dari hal-hal yang sederhana ke hal-hal yang lebih kompleks. Selain itu, pembelajaran yang diselenggarakan hendaknya mengandung kebermaknaan.

Menurut Piaget (dalam Marhaeni, 2013), anak usia Sekolah Dasar yaitu dari umur 6-12 tahun berada pada tahap operasional konkrit. Pada tahap ini anak dapat membuat pemikiran tentang situasi atau hal konkrit secara logis. Karakteristik belajar anak pada tahap ini adalah belajar melalui hal-hal yang bersifat nyata. Namun, beberapa buku yang ditemukan di lapangan tampak masih ada yang tidak menghadirkan situasi konkrit/nyata ke dalam pembelajaran sehingga muncul anggapan bahwa bukubuku tersebut tidak sepenuhnya relevan dengan karakteristik belajar anak usia Sekolah Dasar.

Berdasarkan wawancara yang dilaksanakan pada tanggal 26 Februari 2021 dengan guru kelas IV di SD Hindu 1 Bukian, buku tematik di SD memberikan banyak manfaat bagi pelaksanaan pembelajaran karena buku dikemas dalam bentuk yang menarik, dilengkapi dengan pemetaan KD dan indikator pembelajaran, serta mudah dipahami. Namun, di sisi lain, buku ini dapat membingungkan siswa karena isi buku tidak sesuai dengan lingkungan dan budaya tempat siswa belajar. Ruminiati dan Andajani (2016) mengemukakan bahwa Teknik penyajiannya Buku Tematik di SD cenderung tidak mendukung prosedur dalam pendekatan saintifik yang diwajibkan dalam Kurikulum 2013. Nuansa dan pola lama masih dapat ditemui di beberapa bagian dalam buku tersebut, seperti langsung menyajikan materi tanpa memberi kesempatan kepada siswa untuk mengamati, menanya, menalar, dan mencoba. Dharma (2019) juga mengungkapkan bahwa pembelajaran bermakna akan tercipta apabila anak mampu mengembangkan kemampuan berpikir naratif, dan memiliki rasa ingin tahu yang tinggi.

Adanya kecenderungan seperti ini dipandang perlu untuk membuat suatu inovasi baru bahan ajar yang menyediakan materi agar sesuai dengan kondisi lingkungan setempat. Karakteristik peserta didik di setiap wilayah Indonesia berbeda satu dengan yang lainnya, sehingga perlu dilakukan identifikasi unsur budaya lokal (kearifan lokal) dalam sumber belajar siswa. Putri, dkk (2021) memaparkan pengenalan nilai kearifan lokal pada siswa sekolah dasar diantaranya dapat bermanfaat untuk menciptakan karakter cinta tanah air sehingga siswa dapat mengenal dan melestarikan budaya daerahnya. Dimana tujuannya tak lain agar pembelajaran yang dirasakan oleh siswa bernilai guna dan bermakna. Pembelajaran bermakna akan dapat diperoleh jika anak belajar sesuai dengan lingkungan sosialnya, sehingga 
unsur budaya tidak bisa dilepaskan dalam merancang sebuah pembelajaran di sekolah. Selain itu, dalam kerangka kurikulum 2013 juga disebutkan bahwa dalam menyusun dan mengembangkan kegiatan pembelajaran harus memperhatikan prinsip-prinsip penyusunan dan pengembangan sesuai dengan kondisi di satuan pendidikan baik kemampuan awal peserta didik, minat, motivasi belajar, bakat, potensi, kemampuan sosial, emosi, gaya belajar, kebutuhan khusus, kecepatan belajar, latar belakang budaya, norma, nilai, dan/atau lingkungan peserta didik (Kemendikbud, 2013).

Hal ini menjadi bahan telaah peneliti untuk dijadikan sebuah kajian untuk dikembangkan di sekolah dasar. Artinya, Konsep literasi yang dimiliki siswa sangat bisa untuk dipadukan dengan pembelajaran tematik berlandaskan konsep kearifan lokal yang dekat dengan lingkungan serta kondisi siswa yaitu melalui pengembangan buku cerita bergambar berkearifan lokal Subak. Dengan mengembangkan buku cerita bergambar berkearifan lokal Subak, pembelajaran tematik di Sekolah Dasar khususnya di Payangan yang mayoritas penduduknya merupakan petani, dapat terlaksana sesuai kondisi lingkungan setempat sehingga pembelajaran yang terjadi tidak membingungkan siswa.

Dharma (2019) menjelaskan bahwa buku cerita anak dapat diangkat dari banyak sisi dan latar belakang. Namun, cerita yang dirasa baik adalah cerita-cerita yang berasal dari budaya lokal. Budaya lokal merupakan sarana yang efektif dalam menanamkan nilai-nilai dan pengetahuan ke dalam diri peserta didik. Seperti nilai budaya lokal Subak yang dapat diangkat menjadi sebuah cerita anak yang menarik untuk siswa.

Kearifan lokal sangat erat kaitannya dengan lingkungan dan alam sekitar. Sehingga dapat dikatakan kearifan lokal dapat dijadikan konsep pembelajaran di Sekolah seperti yang disampaikan oleh Pandapotan dan Silalahi (dalam Pratiwi dan Suwandi, 2021) sebagai berikut:
"Local wisdom can be seen as a learning concept in schools to enhance the local potential of the regions in Indonesia. Various local wisdoms that have been maintained by ethnic groups in Indonesia are learned from nature, and consider everything that is good and useful, which they also learn from nature"

Prasetyo dan Aditama (dalam Pratiwi dan Suwandi, 2021) juga menambahkan bahwa:

"The objective of preserving local knowledge is to improve students' capacity to create and sustain their local wealth in Indonesia, notably in developing cognitive, affective and psychomotor aspects"

Kearifan lokal ini sangat berdampak pada tiga komponen penting dalam pembelajaran yaitu untuk membangun kognitif, afektif serta aspek psikomotor pada diri siswa. Subak yang merupakan kearifan lokal adalah salah satu warisan leluhur yang patut diketahui oleh generasi kita. Tak lain adalah untuk mengenalkan dan mempertahankan eksistensi budaya lokal Bali agar tidak terlupakan di kalangan anak muda.

Dari paparan di atas maka penting dilakukan usaha perbaikan bahan ajar di sekolah dasar. Diharapkan dengan pengembangan bahan ajar yang menekankan pada kearifan lokal subak, siswa memiliki bahan ajar yang valid dan praktis.

\section{METODE}

Jenis penelitian ini adalah penelitian pengembangan, karena yang menjadi fokus dalam penelitian ini adalah pengembangan Buku Cerita bergambar berkearifan lokal Subak dalam tema Peduli terhadap Makhluk Hidup untuk siswa kelas 4 SD. Produk yang dihasilkan diuji validitas dan kepratisannya. Uji validitas dilakukan dengan menggunakan instrument berupa lembar validasi. Uji validitas ini berkaitan dengan kelayakan materi, kelayakan kebahasaan, dan kelayakan kegrafikan. Responden yang dilibatkan dalam uji validitas terdiri dari 2 
orang dosen ahli. Adapun untuk uji kepraktisan dilakukan dengan melibatkan 23 orang siswa dan 3 orang guru sebagai responden.

Penelitian ini menggunakan model penelitian 4-D adalah model yang dikembangkan oleh $\mathrm{S}$. Thagarajan, Dorothy S. Sammel, dan Melvyn I. Sammel. Model 4D terdiri dari empat tahap pengembangan yaitu define, design, develope, dan disseminate (Batubara, 2017).

Pada tahap define dilakukan kegiatan analisis tema dan subtema, analisis kompetensi dasar, mendefinisikan perilaku yang sesuai dengan muatan kearifan lokal dan penggambaran tokoh cerita. Kemudian pada tahap design peneliti mengembangkan bentuk permulaan (draft) dari produk yang dihasilkan dengan menyusun bagian awal, isi dan penutup buku cerita. Isi buku cerita didasarkan pada kompetensi dasar dan indikator yang sudah ditetapkan.

Dalam peneltian ini juga dirumuskan lembar validasi, format respon guru terhadap buku cerita yang dikembangkan, format respon siswa terhadap buku cerita yang dikembangkan. Rancangan instrumen tersebut selanjutnya divalidasi dan digunakan untuk menilai validitas dan kepraktisan buku cerita yang dikembangkan.

Lembar validasi diisi oleh 2 orang dosen ahli. Peneliti mengirimkan buku hasil pengembangan untuk dinilai oleh 2 orang validator. Penilaian dilakukan dengan merespon 35 butir pernyataan yang memiliki rentang skor 1-5 pada lembar validasi yang telah disusun.

Angket respon guru diisi oleh 3 orang guru kelas di Gugus Bukian. Peneliti mengirimkan buku hasil pengembangan untuk dinilai oleh guru tersebut. Penilaian dilakukan dengan merespon 30 butir pernyataan yang memiliki rentang skor 1-5. Sedangkan untuk angket respon siswa buku hasil pengembangan direspon oleh 23 orang siswa kelas 4 SD Negeri Hindu 1 Bukian dengan menjawab 10 pertanyaan dengan alternatif jawaban Ya dan Tidak, Ya dengan skor 1 dan Tidak dengan skor 0 .

Pada tahap develope difokuskan pada pengembangan draft awal menjadi buku cerita yang utuh. Buku cerita dikembangkan berdasarkan tanggapan dan saran dari ahli terhadap kelayakan materi, kelayakan kebahasaan, dan kelayakan kegrafikan. Setelah adanya validasi dari ahli maka selanjutnya buku diujicobakan pada 3 orang guru dan siswa kelas 4 SD Negeri Hindu 1 Bukian sejumlah 23 orang.

Pada tahap disseminate dilakukan penyebarluasan buku cerita agar dapat dimanfaatkan oleh khalayak luas. Dalam penelitian pengembangan ini terdapat dua jenis data penelitian, yaitu data kualitatif yang diperoleh dari tanggapan dan saran ahli dan praktisi (guru) terhadap buku cerita yang dikembangkan dan data kuantitatif diperoleh dari hasil validasi oleh ahli dan praktisi dan hasil pengisian angket respon oleh siswa

Data-data dikumpulkan dengan menggunakan beberapa instrumen yaitu lembar validasi dan angket respon. Lembar validasi dipakai untuk mengumpulkan data tentang validitas buku yang mencakup kelayakan materi, kelayakan kebahasaan, dan kelayakan kegrafikan. Sedangkan angket respon guru digunakan untuk mengumpulkan data tentang tanggapan guru setelah menggunakan buku cerita dalam pembelajaran.

Data kualitatif yang berasal dari tanggapan dan saran dari ahli atas kelayakan materi, kelayakan kebahasaan, dan kelayakan kegrafikan dan tanggapan guru dirangkum dan disimpulkan untuk selanjutnya digunakan sebagai bahan perbaikan rancangan buku sebelum diujicobakan. Sementara data kualitatif yang berasal dari pengisian lembar validasi oleh ahli, dan angket respon guru serta siswa atas kelayakan materi, kelayakan kebahasaan, dan kelayakan kegrafikan diubah menjadi data kuantitatif.

Data kuantitatif selanjutnya dianalisis menurut aspek kelayakan buku yang 
Tabel 3. Kriteria Penilaian Validitas Buku

selanjutnya dihitung rata-rata skor dari setiap aspek. Sumber data kuantitatif aspek kelayakan berasal dari 3 komponen, yaitu kelayakan materi, kelayakan kebahasaan, dan kelayakan kegrafikan.

Teknik analisis data untuk lembar validasi oleh ahli, angket respon guru, dan angket respon siswa dapat dijelaskan sebagai berikut.

Tabel 1. Penskoran Hasil Validasi dan Angket Respon Guru

\begin{tabular}{lc}
\hline Jawaban & Skor \\
\hline Sangat Setuju & 5 \\
Setuju & 4 \\
Cukup Setuju & 3 \\
Kurang Setuju & 2 \\
Sangat Kurang Setuju & 1 \\
\hline
\end{tabular}

Tabel 2. Penskoran Hasil Angket Respon Siswa

\begin{tabular}{lc}
\hline Jawaban & Skor \\
\hline Ya & 1 \\
Tidak & 0 \\
\hline
\end{tabular}

Untuk menghitung rata-rata skor dari kriteria penilaian validitas dan kepraktisan oleh guru dengan rumus:

$\bar{X}_{0}=\frac{\sum x}{n}$

Keterangan:

$\bar{X} \quad=$ Skor rata-rata seluruh aspek

$\sum x=$ Jumlah skor seluruh aspek

$\mathrm{n} \quad=$ Banyaknya butir pernyataan

Kemudian untuk menghitung rata-rata skor dari kriteria penilaian kepraktisan oleh siswa dengan rumus:

$$
\begin{aligned}
& P=\frac{a}{b} \times 100 \% \\
& \text { Keterangan: } \\
& P=\text { Persentase } \\
& a=\text { Jumlah aspek dengan pilihan } \mathrm{Ya} \\
& \mathrm{b}=\text { Jumlah maksimal }
\end{aligned}
$$

Sedangkan untuk menetapkan kriteria validitas dan kepraktisan menggunakan Tabel 3, 4 dan 5.

\begin{tabular}{ll}
\multicolumn{1}{c}{ Cerita } \\
\hline Interval & Kategori \\
\hline $4,2<x$ & Sangat Valid \\
$3,4<x \leq 4,2$ & Valid \\
$2,6<x \leq 3,4$ & Cukup Valid \\
$1,8<x \leq 2,6$ & Kurang Valid \\
$x \leq 1,8$ & Tidak Valid \\
\hline \multicolumn{2}{c}{ (dimodifikasi dari Sutariani, 2019:58) }
\end{tabular}

Tabel 4. Kriteria Penilaian Kepraktisan Buku Cerita untuk Respon Guru

\begin{tabular}{ll}
\hline Interval & Kategori \\
\hline $4,2<x$ & Sangat Praktis \\
$3,4<x \leq 4,2$ & Praktis \\
$2,6<x \leq 3,4$ & Cukup Praktis \\
$1,8<x \leq 2,6$ & Kurang Praktis \\
$x \leq 1,8$ & Tidak Praktis \\
\hline \multicolumn{2}{c}{ (dimodifikasi dari Sutariani, 2019:58) }
\end{tabular}

Tabel 5. Kriteria Penilaian Kepraktisan Buku Cerita untuk Respon Guru

\begin{tabular}{ll}
\hline Persentase & Kategori \\
\hline $0 \%-20 \%$ & Sangat Praktis \\
$21 \%-40 \%$ & Praktis \\
$41 \%-60 \%$ & Cukup Praktis \\
$61 \%-80 \%$ & Kurang Praktis \\
$81 \%-100 \%$ & Tidak Praktis \\
\hline \multicolumn{2}{c}{ (dimodifikasi dari Dwiningsih, 2018:162) }
\end{tabular}

\section{HASIL DAN PEMBAHASAN}

Pada penelitian ini buku cerita yang dikembangkan difokuskan pada tema "Peduli Terhadap Makhluk Hidup", subtema "Keberagaman Makhluk Hidup di Lingkunganku", pembelajaran 5. Untuk menginsersi nilai-nilai Tri Hita Karana ke dalam buku cerita berkearifan lokal pada proses pembelajaran secara tematik atau terinsersi dalam mata pelajaran sesuai dengan isi kurikulum tentu guru harus menyiapkan perencanaan yang matang dan menyeluruh. Pemilihan materi pembelajaran yang dapat diinsersi nilai-nilai Tri Hita Karana tentu harus dilakukan dengan tepat, agar mampu tersampaikan dengan baik kepada peserta didik.

Berdasarkan tema dan subtema yang ditentukan, pemilihan kompetensi dasar 
didasarkan pada pembelajaran 5 yang terdapat pada subtema 2. Kompetensi dasar tersebut kemudian diturunkan ke dalam indikator. Muatan Pembelajaran IPA dengan indikator mendeskripsikan daur hidup beberapa jenis makhluk hidup, Muatan Pembelajaran IPS dengan indikator memahami manusia dalam dinamika interaksi dengan lingkungan alam, sosial, budaya, dan ekonomi dan Muatan Pembelajaran SBdK dengan indikator Mengenal karya dua dimensi dan tiga dimensi berdasarkan pengamatan.

Narasi pada buku cerita didasarkan pada indikator tersebut. Nilai-nilai ajaran Tri Hita Karana diinsersi dalam aktivitas dan percakapan yang dilakukan oleh para tokoh dalam buku cerita berkearifan lokal "Melali ke Subak Tiyingan".

Dalam buku cerita "Melali ke Subak Tiyingan", diceritakan ada tiga sekawan yang sangat hobi berpetualang. Mereka adalah Ngakan, Made dan Ngurah. Mereka sangat suka sekali menghabiskan waktu bersama. Tempat yang mereka sering kunjungi adalah sawah.

Tiga sekawan ini digambarkan sebagai tokoh yang gemar mencari tahu dan antusias terhadap hal baru. Seperti halnya ingin mencari tahu bagaimana bisa air tak henti-hentinya mengalir, siapa yang membuang sampah di genangan air irigasi, apa yang dimaksud subak, dan berbagai hal lainnya.

Di luar dari tokoh tiga sekawan ini, ada tokoh Pekak Rarud yang merupakan seorang kakek tua yang sangat berpengalaman di bidang pertanian. Pekak Rarud digambarkan sebagai tokoh yang informatif. Sehingga apapun yang ingin diketahui tiga sekawan ini, Pekak Rarud dapat menyampaikannya dengan lugas. Tentunya dengan menggunakan bahasa anak yang mudah dipahami.

Penelitian ini menggunakan model $4 D$ diantaranya tahap define, design, develope, dan disseminate. Kegiatan yang dilakukan pada keempat tahapan tersebut diantaranya yang pertama tahap define (pendefinisian).
Pada tahap ini dilakukan analisis terhadap tema, subtema serta kompetensi dasar dan merumuskan indikator. Pada tahap ini juga dilakukan pendefinisikan perilaku tokoh serta penggambaran tokoh tiga sekawan dan salah satu tokoh informatif, Pekak Rarud. Dalam tahap ini dikumpulkan data yang menjadi bahan atau materi buku cerita. Data-data yang terkumpul berguna untuk menentukan rancangan buku cerita dan instrumen yang dibuat.

Selanjutnya tahap design (perancangan). Pada tahap ini dilakukan perancangan draft. Buku cerita bergambar yang dimaksud merupakan media cetak dengan ukuran Square $(20 \mathrm{~cm} \times 20 \mathrm{~cm})$ yang menginsersi nilai-nilai Tri Hita Karana dalam cerita berkearifan lokal sebagai berikut. 1) Parhyangan, hubungan harmonis antara manusia dengan Sang Pencipta. 2) Pawongan, hubungan yang harmonis antar sesama manusia. 3) Palemahan, hubungan yang harmonis antara manusia dengan lingkugannya.

Tri Hita Karana sebagai tiga pondasi keharmonisan hidup bermasyarakat di Bali dapat dijadikan acuan bertingkah laku siswa. Sehingga ketika buku cerita ini dikembangkan siswa dapat mencontoh perilaku yang ditampilkan oleh tiga sekawan yang merupakan tokoh utama di dalam cerita.

Umumnya tokoh anak kecil dalam cerita merupakan tokoh yang sangat diminati siswa sehingga tokoh-tokoh tersebut bisa menjadi teladan siswa. Pengenalan tokoh tiga sekawan didukung dengan adanya tokoh Pekak Rarud yang sangat informatif. Sehingga melengkapi kesempurnaan buku cerita ini. Buku cerita menjadi padat berisi dengan dilengkapi pengetahuan-pengetahuan dasar mengenai subak, pertanian serta pengetahuan mengenai alam sekitar yang berguna untuk keharmonisan hidup di lingkungan tempat siswa tinggal.

Pada tahap ini juga disusun rancangan instrumen penelitian, untuk menilai validitas dan kepraktisan buku 
cerita. Instrumen yang telah dirancang berupa lembar validasi dan angket respon guru dan angket respon siswa.

Berikutnya tahap develope (pengembangan). Pada tahap ini draft buku cerita yang telah dirancang pada tahap design disempurnakan sehingga produk dapat diuji validitasnya oleh 2 orang ahli.

Tampilan Produk Buku Bergambar yang berjudul "Melali ke Subak Tiyingan" dapat dilihat pada Gambar 1 berikut.

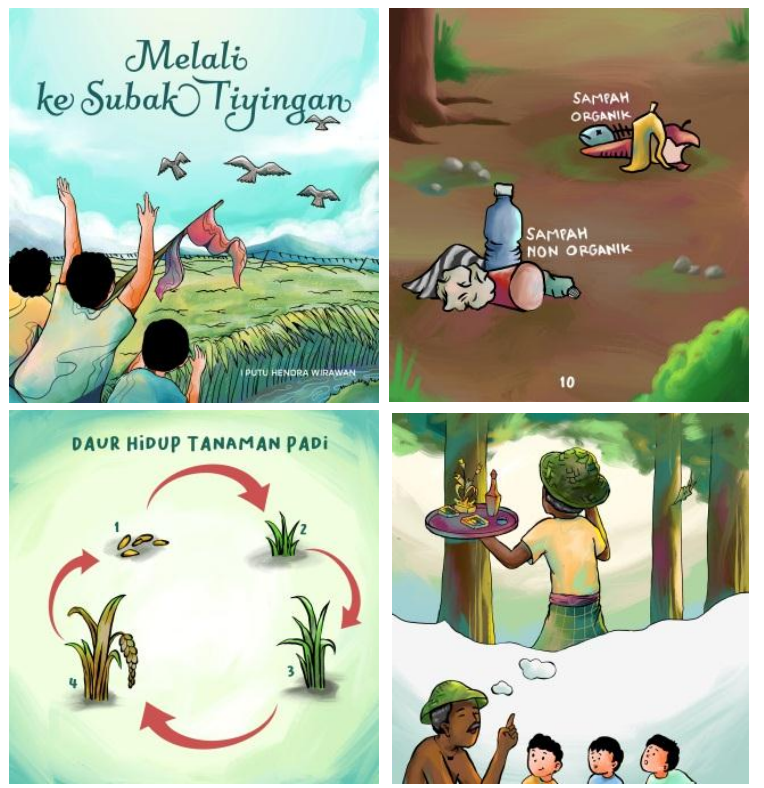

Gambar 1. Isi Buku yang Telah Memuat lustrasi

Produk yang telah divalidasi dan direvisi sesuai masukan dan saran ahli kemudian diuji cobakan dalam pembelajaran. Selanjutnya buku yang sudah divalidasi diujicobakan pada 3 orang guru dan 23 orang siswa di SD Negeri Hindu 1 Bukian. Buku cerita digunakan pada kegiatan pembelajaran dan di akhir pembelajaran guru dan siswa mengisi angket respon yang berkaitan dengan buku cerita.

Validitas buku diuji dengan menggunakan lembar validasi. Septiani (dalam Agatha, 2017:61) mengatakan bahwa Uji validasi ini dilakukan oleh para ahli. Kegiatan validasi dapat dilakukan oleh beberapa ahli yang sudah berpengalaman guna menilai kelebihan dan kelemahan produk yang telah dihasilkan.

Validasi Buku Cerita Bergambar dengan menginsersi nilai-nilai Tri Hita Karana dalam buku cerita berkearifan lokal pada tema peduli terhadap makhluk hidup untuk siswa kelas 4 SD ini dilakukan oleh 2 orang dosen ahli.

Pada instrumen lembar validasi terdapat 35 butir pernyataan yang terdiri dari 19 butir pernyataan tentang kelayakan materi, 8 butir pernyataan tentang kelayakan kebahasaan dan 8 butir pernyataan tentang kelayakan kegrafikan. Penilaian tertinggi dengan skala "Sangat Baik" dengan nilai 5 dan penilaian terendah dengan skala "Sangat Kurang Baik" dengan nilai 1. Jumlah nilai maksimal untuk kelayakan materi adalah 95, kelayakan kebahasaan 40 dan kelayakan kegrafikan 40. Jumlah nilai minimal untuk kelayakan materi adalah 19, kelayakan kebahasaan 8 dan kelayakan kegrafikan 8 . Sehingga 35 butir pernyataan tersebut memiliki nilai maksimal 175 dan nilai minimal 35 .

Ahli pertama memberikan penilaian terhadap validitas isi buku dengan jumlah nilai 175 , dengan rincian sebagai berikut: kelayakan materi dengan nilai 95, kelayakan kebahasaan dengan nilai 40 dan kelayakan kegrafikan dengan nilai 40. Ahli kedua memberikan penilaian terhadap validitas isi buku dengan jumlah nilai 169, dengan rincian sebagai berikut: kelayakan materi dengan nilai 89 , kelayakan kebahasaan dengan nilai 40 dan kelayakan kegrafikan dengan nilai 40 .

Jumlah nilai masing-masing Ahli dibagi dengan banyak butir pernyataan sehingga diperoleh skornya. Ahli pertama memberikan skor 5, Ahli kedua memberikan skor 4.82. Kedua skor tersebut kemudian dirata-ratakan sehingga memperoleh hasil 4.91. Skor rata-rata 4.91 termasuk ke dalam interval dengan kategori "Sangat Valid"

Untuk menguji kepraktisan, buku diuji cobakan secara terbatas, yaitu pada 3 orang guru dan 23 orang siswa. Septiani (dalam Agatha, 2017:62) memandang 
kepraktisan bahan ajar berkaitan dengan kemudahan penggunaan bahan ajar yang telah dikembangkan. Nieveen (dalam Sutariani, 2019: 117) menyatakan "karakteristik suatu produk pendidikan mempunyai kualitas kepraktisan yang tinggi apabila ahli dan guru mempertimbangkan produk itu dapat digunakan dan realitanya menunjukkan mudah bagi guru dan siswa untuk menggunakan produk tersebut. Ini berarti terdapat konsistensi antara harapan dengan pertimbangan, dan harapan dengan operasional. Oleh karena itu, di akhir uji coba praktisi dan siswa diminta untuk memberikan penilaian terhadap buku dengan menggunakan angket respon."

Angket respon yang disusun yaitu angket respon guru dan siswa. Angket respon guru terdiri atas 30 butir pernyataan yang terdiri dari 5 butir pernyataan tentang ketertarikan terhadap isi buku, 20 butir pernyataan tentang materi dan 5 butir pernyataan tentang bahasa. Penilaian tertinggi dengan skala "Sangat Baik" dengan nilai 5 dan penilaian terendah dengan skala "Sangat Kurang Baik" dengan nilai 1. Jumlah nilai maksimal untuk ketertarikan adalah 25, jumlah nilai maksimal untuk materi adalah 100 dan jumlah nilai maksimal untuk bahasa adalah 25 . Jumlah nilai minimal untuk ketertarikan adalah 5 , jumlah nilai minimal untuk materi adalah 20 dan jumlah nilai minimal untuk bahasa adalah 5 . Sehingga 30 butir pernyataan tersebut memiliki nilai maksimal 150 dan nilai minimal 30.

Guru memberikan penilaian terhadap kepraktisan buku dengan jumlah nilai 145 , dengan rincian sebagai berikut: aspek ketertarikan dengan nilai 25 , aspek materi dengan nilai 95 dan aspek bahasa dengan nilai 25 . Jumlah tersebut dibagi dengan banyak butir pernyataan sehingga diperoleh skornya. Skor yang diberikan oleh guru dalam angket respon tersebut sebesar 4,28 yang termasuk ke dalam interval dengan kategori "Sangat Praktis".

Angket respon siswa terdiri atas 10 butir pertanyaan yang dirinci sebagai berikut. 5 butir pertanyaan tentang ketertarikan terhadap isi buku, 3 butir pertanyaan tentang materi dan 2 butir pertanyaan tentang bahasa. Respon diisi dengan Ya dan Tidak, Ya bernilai 1 dan Tidak bernilai 0 . Sehingga jumlah nilai maksimalnya adalah 10 dan nilai minimalnya 0 . Dari hasil pengisiian angket oleh 23 orang siswa diperoleh hasil sebagai berikut: aspek ketertarikan memperoleh jumlah nilai 110 , aspek materi memperoleh jumlah nilai 64 , dan aspek kebahasan memperoleh nilai 44. Jumlah nilai keseluruhan aspek yaitu 218 kemudian dibagi dengan jumlah maksimal nilai keseluruhan aspek dari 23 siswa yaitu 230 dan dikalikan 100 sehingga memperoleh persentase sebesar $94 \%$ yang termasuk ke dalam interval dengan kategori "Sangat Praktis"

Berdasarkan hasil pengembangan disertai dengan validasi dari 2 orang dosen ahli, maka buku cerita bergambar berkearifan lokal subak dalam tema peduli terhadap makhluk hidup untuk siswa kelas 4 SD ini dinilai sangat valid sehingga dapat digunakan dalam pembelajaran. Selanjutnya berdasarkan hasil analisis respon guru dan siswa buku cerita bergambar berkearifan lokal subak dalam tema peduli terhadap makhluk hidup untuk siswa kelas 4 SD juga dinyatakan sangat praktis digunakan dalam pembelajaran.

Pada tahap disseminate seharusnya buku cerita hasil pengembangan yang berjudul "Melali ke Subak Tiyingan" disebarluaskan untuk kepentingan pendidikan. Namun karena keterbatasan peneliti buku cerita ini belum dapat disebarkan ke khalayak umum dan hanya disebarluaskan pada lingkup penelitian saja, yakni pada guru dan siswa yang menjadi subjek penelitian.

Buku cerita diharapkan dapat membantu guru dalam mentransfer ilmu ke siswa, karena selain mendidik dengan adanya ilustrasi pada buku maka siswa akan tertarik untuk membacanya. Warsa (2018:81) juga berpendapat bahwa sastra 
merupakan media yang tepat untuk pembentukan karakter dan sikap sosial spritual. Dengan demikian, penelitian ini telah menghasilkan produk berupa buku cerita bergambar berkearifan lokal subak dalam tema peduli terhadap makhluk hidup untuk siswa kelas 4 SD yang valid dan praktis.

\section{PENUTUP}

Berdasarkan pada hasil penelitian dan pembahasan yang telah dikemukakan sebelumnya, maka dapat disimpulkan beberapa hal sebagai berikut. 1) Uji validitas dengan melibatkan 2 orang dosen ahli, diperoleh hasil analisis dengan rata-rata "4.91" dengan demikian buku cerita bergambar berkearifan lokal subak dalam tema peduli terhadap makhluk hidup untuk siswa kelas 4 SD termasuk ke dalam kategori "sangat valid". 2) Kepraktisan Buku Cerita Bergambar berkearifan lokal subak dalam tema peduli terhadap makhluk hidup untuk siswa kelas $4 \mathrm{SD}$, diukur berdasarkan hasil analisis terhadap angket respon guru diperoleh rata-rata " 4.28 " dengan kategori "sangat praktis". 3) Kepraktisan Buku Cerita Bergambar berkearifan lokal subak dalam tema peduli terhadap makhluk hidup untuk siswa kelas $4 \mathrm{SD}$, diukur berdasarkan hasil analisis terhadap angket respon siswa diperoleh persentase "94\%" dengan kategori "sangat praktis".

Berdasarkan simpulan yang dikemukakan tersebut, maka peneliti merekomendasikan hal-hal berikut. 1) Buku cerita ini dapat digunakan untuk menambah keragaman bahan ajar, khususnya pembelajaran tematik di sekolah dasar sehingga dapat bermanfaat bagi siswa. 2) Buku cerita ini dapat bermanfaat bagi kemampuan literasi siswa serta sebagai acuan bertingkah laku di sekolah, keluarga dan masyarakat. 3) Buku cerita bergambar ini dapat dijadikan sebagai bahan ajar yang dapat digunakan untuk memberikan pengetahuan dasar tentang subak dan lingkungan agar siswa peduli terhadap alam di sekitar mereka. 4) Buku cerita ini dapat dijadikan acuan bagi peneliti lain yang ingin mengembangkan produk sejenis. 5) Buku hasil penelitian ini baru diuji cobakan secara terbatas, sehingga peneliti lain dapat melanjutkan penelitian dalam uji coba yang lebih luas.

\section{DAFTAR PUSTAKA}

Agatha, Nabiela Dini, dkk. 2017. "Pengembangan Buku Komik Pokok Bahasan Sistem Peredaran Darah." Jurnal Bioedukatika, Vol. 5 No. 2 Halaman 59-64. Tersedia pada http://journal.uad.ac.id/index.php/BIOE DUKATIKA/article/view/7200 (diakses tanggal 2 Maret 2021).

Batubara, Hamdan Husein. 2017. "Pengembangan Media Pembelajaran Matematika berbasis Android untuk Siswa SD/MI". Muallimuna Jurnal Penelitian Ibtidaiyah, Volume 3, Nomor 1, 2017, hlm. 12-27. Tersedia pada https://ojs.uniskabjm.ac.id/index.php/jurnalmuallimuna/ article/view/952 (diakses tanggal 5 Maret 2021).

Dharma, I Md Aditya. 2019. "Pengembangan Buku Cerita Anak Bergambar dengan Insersi Budaya Lokal Bali terhadap Minat Baca dan Sikap Siswa Kelas V SD Kurikulum 2013". Journal for Lesson and Learning Studies, Volume 2, Nomor 1, 2019. Tersedia pada https://ejournal.undiksha.ac.id/index.p hp/JLLS/article/view/17321 (diakses tanggal 14 Maret 2021).

Majid, Abdul. 2017. Pembelajaran Tematik Terpadu. Bandung: PT Remaja Rosdakarya.

Marhaeni, A. A. I. N. 2013. Landasan dan Inovasi Pembelajaran. Singaraja: Universitas Pendidikan Ganesha.

Peraturan Menteri Pendidikan dan Kebudayaan Nomor 67 Tahun 2013 Tentang Kerangka Dasar dan Struktur Kurikulum Sekolah Dasar/ Madrasah 
Diterima : 31-09-2021 | Disetujui : 24-09-2021 | Diterbitkan : 28-09-2021

Ibtidaiyah. $2013 . \quad$ Jakarta:

Kemendikbud.

Pratiwi, Veronika U., Suwandi, Sarwiji. 2021. "Local Wisdom in the Picture Storybook for Elementary School Students in Sukoharjo Regency". Budapest International Research and Critics Institute-Journal (BIRClJournal),Volume 4, No. 1, 2021, hlm. 1262-1271. Tersedia pada http://www.bircujournal.com/index.php/birci/article/view 11751/pdf (diakses tanggal 5 Maret 2021).

Putri, Qonita dkk. 2021. "Desain Buku Cerita Anak Berbasis Nilai Kearifan Lokal Untuk Pembelajaran Teks Fiksi Siswa Kelas IV Sekolah Dasar". Caruban: Jurnal Ilmiah Pendidikan Dasar, Volume 4, Nomor 1, 2021, hlm. 20-33. Tersedia pada http://jurnal.ugj.ac.id/index.php/Caruba n/article/view/4812 (diakses tanggal 8 Maret 2021).

Ruminiati dan Andajani. 2016. "Analisis Kesusuaian Isi Buku Tematik Kelas IV Sekolah Dasar dengan Pendidikan Karakter, dan Pendekatan Scientific". Sekolah Dasar: Kajian Teori dan Praktik Pendidikan, Tahun 25, Nomor 1 Mei 2016. Tersedia pada http://journal2.um.ac.id/index.php/sd/a rticle/view/1310/676 (diakses tanggal 6 Maret 2021).

Sutariani Desak Putu.2019. Pengembangan Buku Teks Matematika Kurikulum 2013 Bermuatan Keterampilan Abad Ke-21 (4c) Untuk Kelas VI Sekolah Dasar. Tesis.Singaraja: Universitas Pendidikan Ganesha.

Warsa, I Komang. 2018. Nilai-Nilai Spiritual dan Karakter dalam Sastra. Denpasar: Balai Bahasa Bali. 